\title{
Direct Synthesis of Vinylene Carbonates from Aromatic Aldehydes
}

\author{
Killian Onida, Leyli Ibrahimli, Nicolas Duguet*
}

Université de Lyon, Université Claude Bernard Lyon 1, CNRS, INSA-Lyon, CPE-Lyon, Institut de Chimie et Biochimie Moléculaires et Supramoléculaires, ICBMS, UMR 5246, team CAtalyse, SYnthèse et ENvironnement (CASYEN), Bâtiment Lederer, 1 rue Victor Grignard, F-69100 Villeurbanne, France.

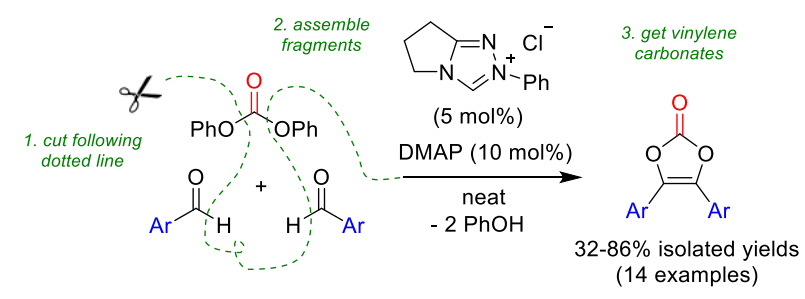

\begin{abstract}
Substituted vinylene carbonates were directly prepared from aromatic aldehydes following a one-pot Benzoin condensation / transcarbonation sequence under solvent-free conditions. The combination of a $N$-phenyl substituted triazolium salt NHC precursor and 4-dimethylaminopyridine (DMAP) was found essential to reach high yield and selectivity. The reaction scope was investigated with a range of aromatic aldehydes and the corresponding vinylene carbonates were obtained with $32-86 \%$ isolated yields (14 examples).
\end{abstract}

Organic carbonates are environmentally-friendly and sustainable species that are the subject of intense research efforts. For instance, they can be used as electrolyte additives in lithium batteries, ${ }^{1}$ as organic solvents ${ }^{2}$ and for the production of polycarbonates $^{3}$ and polyurethanes. ${ }^{4}$ The chemistry of organic cyclic carbonates has been developed extensively, due to the fact that they can be prepared through cycloaddition of epoxides with $\mathrm{CO}_{2},{ }^{5}$ thus giving saturated species. On the opposite, the chemistry of unsaturated cyclic carbonates, i.e. vinylene carbonates, is considerably underdeveloped.

Unsubstituted vinylene carbonate (1,3-dioxol-2-one) is the parent member of the vinylene carbonate family. For instance, it can be used as an electrolyte additive in lithium batteries ${ }^{6}$ or as a monomer to prepare poly(vinylenecarbonate), ${ }^{7}$ a precursor of poly(hydroxymethylene) that could be used in 3D printing. ${ }^{8}$ In organic chemistry, it is mainly used as a dienophile in DielsAlder reactions. ${ }^{9}$ Recently, the chemistry of vinylene carbonate has blossomed notably in annulation reactions ${ }^{10}$ where it serves as acetylene, ${ }^{11}$ acetaldehyde, ${ }^{12}$ acetyl, ${ }^{13}$ or ethynol ${ }^{14}$ surrogates.

Substituted vinylene carbonates are also useful compounds that provide complementary applications. For example, 4,5-dimethyl-1,3-dioxol-2-one is the key precursor of a cleavable group that is used in prodrugs such as olmesartan medoxomil ${ }^{15}$ and azilsartan medoxomil. ${ }^{16}$ Recently, it was also demonstrated that functionalized dioxolone derivatives can be used to prepare excellent polymeric additives to make high-energy-density lithium-ion batteries. ${ }^{17}$

Only a few approaches to substituted vinylene carbonates have been reported in the literature. The silver-catalyzed cycloaddition of propargylic alcohols with $\mathrm{CO}_{2}$ gives exo-vinylene carbonate intermediates (Scheme 1, a). ${ }^{18}$ However, only a few of these species can be isomerized to vinylene carbonates, ${ }^{19}$ thus limiting the scope of application. A wider range of vinylene carbonates can be obtained from benzoins and acyloins by reaction with carbonyl sources such as phosgene, ${ }^{20}$ triphosgene ${ }^{21}$ and carbonyl diimidazole (CDI) (Scheme 1, b). ${ }^{22}$ However, these carbonyl sources are either too toxic or expensive to envision further utilization on the large scale.

Scheme 1. Synthetic strategies to substituted vinylene carbonates.

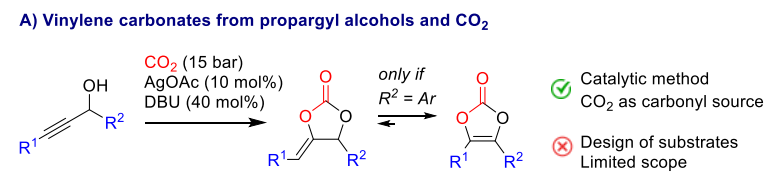

B) Vinylene carbonates from benzoins / acyloins and carbonyl sources

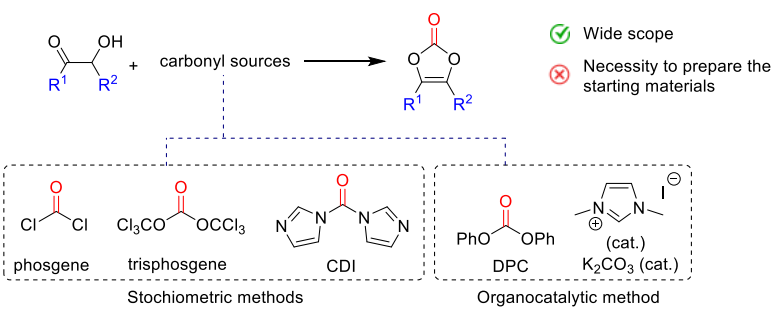

C) Vinylene carbonates from aldehydes and diphenyl carbonate [this work]

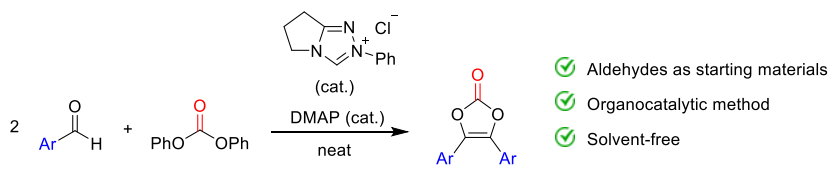


Moreover, our group has recently demonstrated that less toxic (but less reactive) diphenyl carbonate (DPC) can also be used as a carbonyl source, provided activation through organocatalysis. ${ }^{23}$ This method is probably the most general in term of scope, however, it still requires the preliminary preparation of benzoins and acyloins. In this context, we report here the direct synthesis of vinylene carbonates from aldehydes. The reaction occurs through an unprecedented Benzoin condensation/transcarbonation sequence catalyzed by a mixture of a triazolium salt and 4-dimethylaminopyridine (DMAP).

Initial optimization reactions were performed using benzaldehyde $\mathbf{1}$ and diphenyl carbonate $\mathbf{2}$ as model substrates. The screening of catalysts was carried out in order to find a suitable species able to catalyze both transformations and was performed in the presence of $\mathrm{K}_{2} \mathrm{CO}_{3}$ in neat conditions (Table 1). Considering that imidazolium salts were found effective to promote the formation of vinylene carbonates in our previous work, ${ }^{23}$ optimization reactions were first carried out with these species. In sharp contrast, the use of NHC precursors A-F gave poor yields for either benzoin $\mathbf{3}$ or the desired vinylene carbonate $\mathbf{4}$ (entries 1-6). Benzothiazolium salts $\mathbf{G - H}$ and thiazolium salt $\mathbf{I}$ also gave poor yield of $\mathbf{4}$, but slightly promote the formation of $\mathbf{3}$ with up to $10 \%$ yield (entries 7-9). Among triazolium salts, NHC precursor $\mathbf{J}$ did not catalyze the reaction (entry 10). On the contrary, the use of $\mathbf{K}$ led to formation of $\mathbf{4}$ with $9 \%$ yield along with $40 \%$ of intermediate $\mathbf{3}$ (entry 11). Vinylene carbonate $\mathbf{4}$ was also obtained with $10 \%$ yield with $\mathbf{L}$ but this catalyst proves to be more selective as only $2 \%$ of 3 was formed (entry 12). Consequently, this catalyst was selected for further optimization.

Table 1. Screening of NHC precursors ${ }^{a}$

\begin{tabular}{|c|c|c|c|}
\hline $\begin{array}{l}\mathrm{Ph}_{\mathrm{H}} \\
1(2 \mathrm{mmol})\end{array}$ & $\begin{array}{l}\mathrm{Ph}_{-} \mathrm{N}_{\mathrm{O}^{-}} \mathrm{Ph} \\
2(1.1 \mathrm{mmol})\end{array}$ & $\begin{array}{l}\mathrm{HC} \text { presurcor } \\
(5 \mathrm{~mol} \%) \\
\mathrm{CO}_{3}(5 \mathrm{~mol} \%)\end{array}$ & 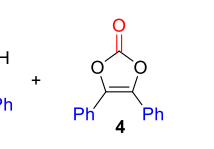 \\
\hline 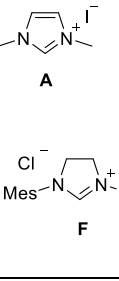 & $\begin{array}{l}\mathrm{R} \\
\mathrm{R}=\mathrm{Et}, \mathrm{X}=\mathrm{Br}, \mathrm{G} \\
\mathrm{C}=\mathrm{I}, \mathrm{H}\end{array}$ & ${ }^{\mathrm{Br}^{-}}$ & 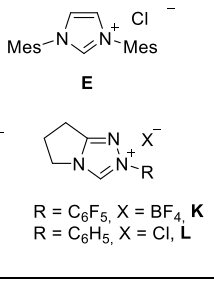 \\
\hline Entry & NHC precursor & Yield $^{b}$ of $\mathbf{3}(\%)$ & Yield $^{b}$ of $\mathbf{4}(\%)$ \\
\hline 1 & $\mathbf{A}$ & 1 & 0 \\
\hline 2 & B & 0 & 0 \\
\hline 3 & $\mathbf{C}$ & 0 & 1 \\
\hline 4 & D & 0 & 1 \\
\hline 5 & $\mathbf{E}$ & 4 & 6 \\
\hline 6 & $\mathbf{F}$ & 0 & 0 \\
\hline 7 & G & 7 & 1 \\
\hline 8 & $\mathbf{H}$ & 3 & 0 \\
\hline 9 & I & 10 & 5 \\
\hline 10 & $\mathbf{J}$ & 0 & 0 \\
\hline 11 & $\mathbf{K}$ & 40 & 9 \\
\hline 12 & $\mathbf{L}$ & 2 & 10 \\
\hline
\end{tabular}

${ }^{a}$ Reaction conditions: benzaldehyde 1 ( $\left.2 \mathrm{mmol}\right)$, diphenyl carbonate (DPC) 2 (1.1 mmol), NHC precursor (5 mol\%), $\mathrm{K}_{2} \mathrm{CO}_{3}(5$ mol\%), $90{ }^{\circ} \mathrm{C}, 16$ h. ${ }^{b}$ Yields were determined by GC/FID with hexadecane as an internal standard.

Several bases ( $5 \mathrm{~mol} \%$ ) were next screened (Table 2). Using carbonates, the yield of $\mathbf{4}$ progressively increased from $0 \%$ with $\mathrm{Li}_{2} \mathrm{CO}_{3}$ to $38 \%$ with $\mathrm{Cs}_{2} \mathrm{CO}_{3}$, while the amount of intermediate 3 remained low (entries 1-5). These results could be explained by the better solubility of cesium carbonate in the neat reaction mixture. Organic bases such as triethylamine (TEA), triazabicyclodecene (TBD) and 1,8-diazabicyclo [5.4.0] undec-7-ene (DBU) gave low yield $(<10 \%)$ for the desired product (entries 6-8). However, 4-dimethylaminopyridine (DMAP) gave an encouraging $57 \%$ yield (entry 9). Increasing its loading to 10 mol\% allows reaching $99 \%$ yield of $\mathbf{4}$, without any traces of benzoin intermediate (entry 10). This excellent result could be explained by the fact that DMAP acts as a base in the Benzoin condensation while also playing the role of a nucleophilic catalyst in the transcarbonation steps. By comparison, NHC precursor $\mathbf{K}$ gave $29 \%$ of $\mathbf{3}$ and $7 \%$ of $\mathbf{4}$, thus confirming the inferiority of this catalyst compared to $\mathbf{L}$ (entry 10 , results in brackets). The catalyst loading of $\mathbf{L}$ was next decreased to 2 and 1 mol\%. In these conditions, the desired vinylene carbonate was formed with only 85 and $57 \%$ yield (entries 11-12). However, the yield of 4 can also reached $99 \%$ when increasing the reaction time to 24 and $64 \mathrm{~h}$, respectively (entries 11-12, results in brackets).

Table 2. Base optimization ${ }^{a}$

\begin{tabular}{|c|c|c|c|}
\hline $1(2 \mathrm{mmol})$ & 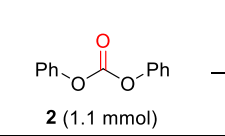 & $\underset{\substack{\text { neat } \\
90^{\circ} \mathrm{C}, 16 \mathrm{~h}}}{\stackrel{\mathrm{L}(5 \mathrm{~mol} \%)}{\text { pase }(5 \mathrm{~mol} \%)}}$ & $\mathrm{P}_{\mathrm{Ph}}^{\mathrm{OH}}+{ }_{\mathrm{Ph}}^{\gamma_{4}}=\gamma_{\mathrm{Ph}}^{\mathrm{O}}$ \\
\hline Entry & $\begin{array}{l}\begin{array}{l}\text { Base, loading } \\
(\mathrm{mol} \%)\end{array}\end{array}$ & $\begin{array}{l}\text { Yield }^{b} \text { of } \mathbf{3} \\
(\%)\end{array}$ & $\begin{array}{l}\text { Yield }^{b} \text { of } \mathbf{4} \\
(\%)\end{array}$ \\
\hline 1 & $\mathrm{Li}_{2} \mathrm{CO}_{3}(5)$ & 1 & 0 \\
\hline 2 & $\mathrm{Na}_{2} \mathrm{CO}_{3}(5)$ & 3 & 5 \\
\hline 3 & $\mathrm{~K}_{2} \mathrm{CO}_{3}(5)$ & 2 & 10 \\
\hline 4 & $\mathrm{Rb}_{2} \mathrm{CO}_{3}(5)$ & 1 & 19 \\
\hline 5 & $\mathrm{Cs}_{2} \mathrm{CO}_{3}(5)$ & 2 & 38 \\
\hline 6 & TEA (5) & 2 & 5 \\
\hline 7 & TBD (5) & 1 & 10 \\
\hline 8 & DBU (5) & 2 & 6 \\
\hline 9 & DMAP (5) & 0 & 57 \\
\hline 10 & DMAP (10) & $0(29)^{c}$ & $99(7)^{c}$ \\
\hline $11^{d}$ & DMAP (10) & 0 & $85(99)^{f}$ \\
\hline $12^{e}$ & DMAP (10) & 0 & $57(99)^{g}$ \\
\hline
\end{tabular}

${ }^{a}$ Reaction conditions: benzaldehyde $\mathbf{1}(2 \mathrm{mmol})$, diphenyl carbonate (DPC) $\mathbf{2}(1.1 \mathrm{mmol})$, NHC precursor $\mathbf{L}(5 \mathrm{~mol} \%)$, base $(5$ mol\%), $90{ }^{\circ} \mathrm{C}, 16$ h. ${ }^{b}$ Yields were determined by GC/FID with hexadecane as an internal standard. ${ }^{c}$ results in brackets obtained with $\mathbf{K}(5 \mathrm{~mol} \%),{ }^{d} 2 \mathrm{~mol} \%$ of $\mathbf{L},{ }^{e} 1 \mathrm{~mol} \%$ of $\mathbf{L},{ }^{f} 24 \mathrm{~h},{ }^{g} 64 \mathrm{~h}$.

Several organic carbonates were next tested as a carbonyl source (Scheme 2). Using either dimethyl carbonate (DMC) or diethyl carbonate (DEC) as a carbonyl source, the desired product was not formed but benzoin intermediate $\mathbf{3}$ was obtained with $48 \%$ and $98 \%$ yield, respectively. These results indicate that DMC and DEC are only acting as solvents and are unable 
to act as carbonyl sources under these conditions. Ethylene carbonate (EC) and propylene carbonate (PC) were also tested as they directly arise from the cycloaddition of ethylene oxide or propylene oxide with $\mathrm{CO}_{2}$. Similarly, no vinylene carbonate was formed. Moreover, these species are also poor solvents for the transformation as benzoin was only obtained with $7 \%$ yield. Catechol carbonate gave 4 with only $14 \%$ yield. In sharp contrast, the use of diphenyl carbonate gave the desired product 4 with $99 \%$ yield. The better reactivity of DPC could be explained by the fact that the phenolate ion is by far a better leaving group than other alkoxides.

\section{Scheme 2. Carbonates as carbonyl sources.}

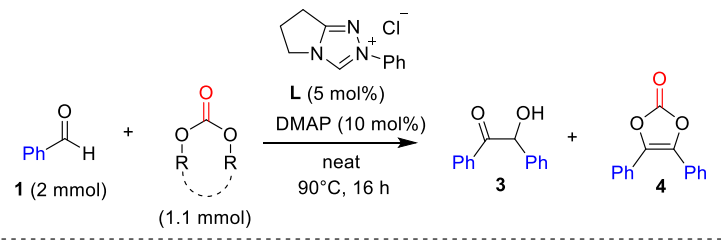

\begin{tabular}{l} 
Carbonates \\
$\begin{array}{l}\begin{array}{l}\text { Yeld of } 3 \\
(\%)\end{array} \\
\begin{array}{l}\text { Yield of } 4 \\
(\%)\end{array}\end{array}$ \\
\hline
\end{tabular}

${ }^{a}$ Reaction conditions: benzaldehyde 1 ( $\left.2 \mathrm{mmol}\right)$, carbonate (1.1 mmol), NHC precursor L (5 mol\%), DMAP (10 mol\%), neat, 90 ${ }^{\circ} \mathrm{C}, 16$ h. ${ }^{b}$ Yields were determined by GC/FID with hexadecane as an internal standard.

The reaction scope was investigated with aromatic aldehydes under optimized conditions (Scheme 3). First, benzaldehyde gave 4 with a good isolated yield of $86 \%$. Benzaldehydes bearing halogens at the para position gave contrasting results. Bromo- and chloro- derivatives worked well with $70-78 \%$ yield for 5-6 while the fluoro derivative gave 7 with only $36 \%$ yield.

Scheme 3. Scope of aromatic aldehydes. ${ }^{a}$

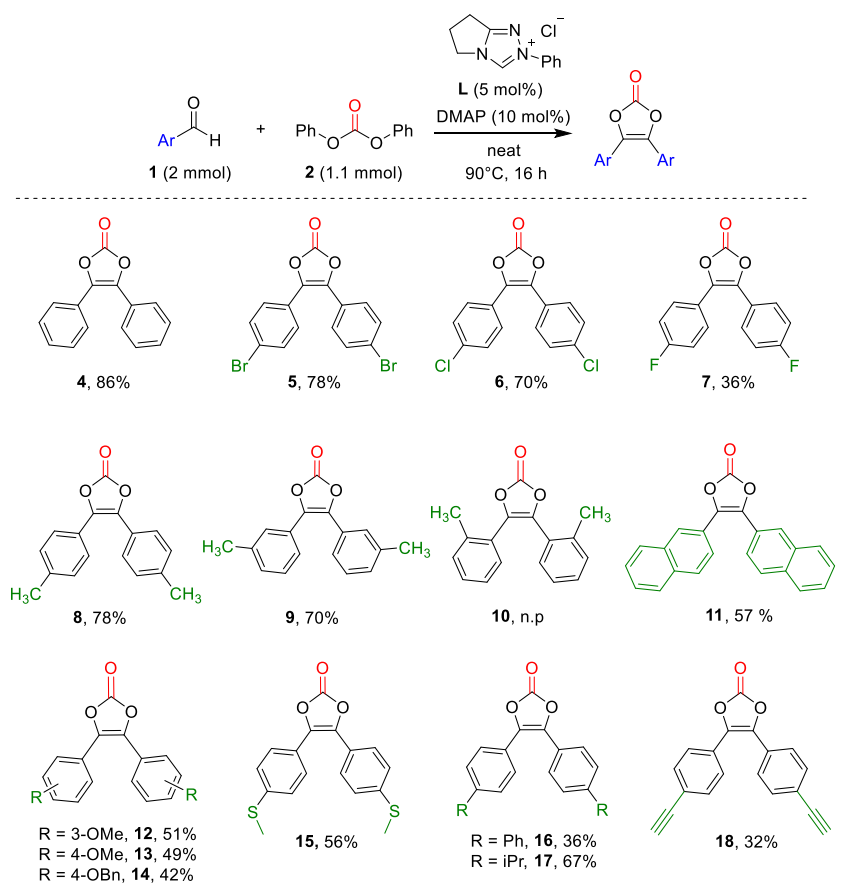

${ }^{a}$ Reaction conditions: aromatic aldehyde $(2 \mathrm{mmol})$, diphenyl carbonate 2 (DPC) (1.1 mmol), NHC precursor $\mathbf{L}$ ( $5 \mathrm{~mol} \%)$, DMAP $(10 \mathrm{~mol} \%), 90{ }^{\circ} \mathrm{C}, 16$ h. n.p: no product.

These results are explained by the fact that the Benzoin condensation does not proceed well with aldehydes bearing strong electron-withdrawing substituents. This was also confirmed with the use of para-nitro and para-trifluorobenzaldehydes that did not convert at all under these conditions. Para- and metatolualdehydes gave the desired vinylene carbonates 8-9 with good yields (70-78\%) while ortho-tolualdehyde did not furnish 10, due to the fact that the Benzoin condensation is also sensitive to steric hinderance. This is also demonstrated with naphthaldehydes. No reaction occurred with $\alpha$-naphthaldehyde while $\beta$-naphthaldehyde gave $\mathbf{1 1}$ with $57 \%$ yield. Aldehydes bearing electron-donating groups such as 3- or 4-anisaldehyde, 4-benzyloxy benzaldehyde and 4-(methylthio)benzaldehyde gave 12-15 with moderate yields (42-56\%). The reaction also proceeds with 4-phenyl-, 4-isopropyl- and 4-ethynylbenzaldehydes and the corresponding vinylene carbonates 16-18 were isolated with $32-67 \%$ yield. The reaction was also attempted with aldehydes bearing free hydroxyl groups such as vanillin and 3-hydroxybenzaldehyde. In these cases, no conversion was observed indicating that the presence of acidic protons is deleterious for the reaction. Finally, aliphatic aldehydes were also tested but only aldolization products were observed under these conditions.

The synthetic utility of substituted vinylene carbonates prepared through the developed methodology was next probed (Scheme 4). First, Suzuki-Miyaura cross-coupling of $5(\mathrm{R}=\mathrm{Br})$ with phenylboronic acid gave $\mathbf{1 6}$ with $72 \%$ yield. Oxidation of $15(\mathrm{R}=\mathrm{SMe})$ with $\mathrm{H}_{2} \mathrm{O}_{2}$ in the presence of acetic acid gave the corresponding bis-sulfoxide $\mathbf{1 9}$ as a 81:19 mixture of diastereomers in $90 \%$ yield. Other transformations were also investigated with vinylene carbonate $4(\mathrm{R}=\mathrm{H})$. Wittig reaction with methylenetriphenylphosphane afforded butenolide $\mathbf{2 0}$ with $62 \%$ yield. Photocyclization in the presence of iodine gave 9,10-dihydrophenanthrene carbonate $\mathbf{2 1}$ with $53 \%$ yield. Finally, hydrogenation under 1 atm of hydrogen in the presence of palladium hydroxide gave $\mathbf{2 2}$ in $91 \%$ yield. These results show that vinylene carbonates offer a unique platform for further transformations.

Scheme 4. Synthetic applications of vinylene carbonates. ${ }^{a}$

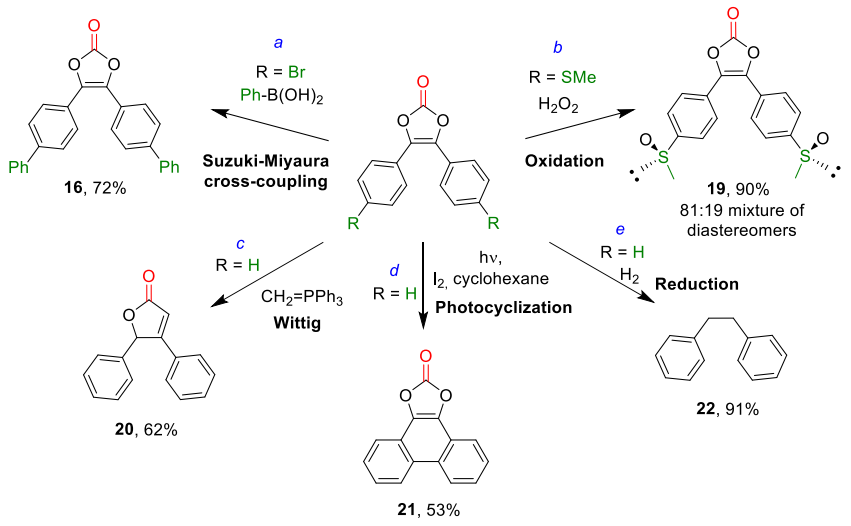

${ }^{a}$ See Supporting Information for experimental details.

From a mechanism point of view, the reaction consists of three steps: i) formation of benzoin intermediate: ii) formation of a mixed carbonate intermediate through trans-carbonation iii) formation of the desired vinylene carbonate by a second 
trans-carbonation. So, some control reactions were performed to understand the role of the base and catalyst for each step. First, control experiments were performed from benzaldehyde (Scheme 5, Control experiments 1). The reaction was carried out with $\mathbf{L}$ alone and with DMAP alone and no conversion was observed in both cases. In contrast, the combination of triazolium $\mathbf{L}$ and DMAP led to full conversion of benzaldehyde and vinylene carbonate 4a was obtained with an excellent $99 \%$ GC yield. These results show that DMAP acts as a base to generate the active species from $\mathbf{L}$, which catalyzes the Benzoin condensation.

\section{Scheme 5. Control experiments. ${ }^{a}$}

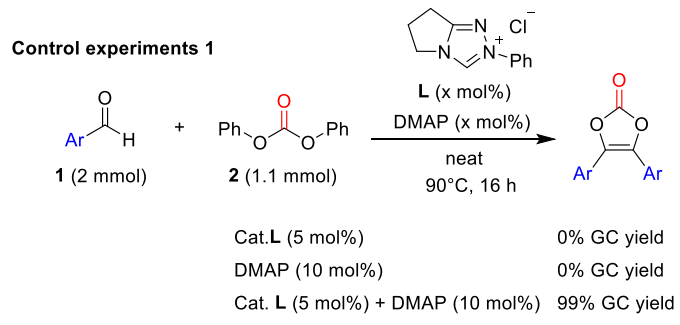

$$
\begin{gathered}
\text { Cat.L }(5 \mathrm{~mol} \%) \\
\text { DMAP }(10 \mathrm{~mol} \%) \\
\text { Cat.L }(5 \mathrm{~mol} \%)+\operatorname{DMAP}(10 \mathrm{~mol} \%)
\end{gathered}
$$

Considering that benzoins were formed as intermediates in this reaction, another series of control experiments was performed using benzoin as a starting material (Scheme 5, Control experiments 2). First, the reaction was performed with $\mathbf{L}$ alone and no conversion of benzoin was observed. On the contrary, when DMAP was used alone, a full conversion was reached and vinylene carbonate 4 a was obtained with $99 \%$ GC yield. Similarly, in the presence of both $\mathbf{L}$ and DMAP, $\mathbf{4 a}$ was also obtained with $99 \%$ GC yield. This result suggests that the free carbene generated from $\mathbf{L}$ and DMAP could also catalyze the transScheme 6. Mechanism proposal. ${ }^{a}$ carbonation steps. This was also demonstrated when using catalyst $\mathbf{L}$ in the presence of $\mathrm{Cs}_{2} \mathrm{CO}_{3}$ as a non-nucleophilic base (see Table 1, entry 5). Moreover, we demonstrated that the formation of vinylene carbonates from benzoins can be catalyzed by $\mathrm{NHCs}^{23}$

So, a reaction mechanism was proposed based on previous works ${ }^{24}$ and the results of control experiments (Scheme 6). First, the triazolium salt $\mathbf{L}$ would be deprotonated by DMAP to give NHC I. Due to huge difference of $\mathrm{pKa}$ values of DMAP $\left(\mathrm{pKa}=9.6,20^{\circ} \mathrm{C} \text { in water }\right)^{25}$ and triazolium salt $\mathbf{L}(\mathrm{pKa}=17.6$, $25^{\circ} \mathrm{C}$ in water), ${ }^{26}$ the direct deprotonation is unlikely but recent works have proposed other pathways, notably through an electrophilic aromatic substitution mechanism. ${ }^{27}$ The nucleophilic addition of the NHC on the first aldehyde gives compound II, then Breslow intermediate ${ }^{28}$ III after 1,2 proton transfer. Nucleophilic addition of III on a second aldehyde gives intermediate $\mathbf{I V}$, which is converted to intermediate $\mathbf{V}$ by 1,4 proton transfer. Finally, benzoin VI is obtained after released of the free carbene. In the second step, diphenyl carbonate would be activated by a nucleophilic catalyst (either DMAP or NHC) to give intermediate VII. Trans-carbonation of VII with benzoin would afford VIII and release a first molecule of phenol. The mixed carbonate intermediate IX would be produced and the nucleophilic catalyst would be released. In the last step, in presence of the nucleophilic catalyst, IX would afford intermediate $\mathbf{X}$ that gives enolate intermediate XI and release a second molecule of phenol. Finally, the enolate XI would add onto the activated carbonyl group to form vinylene carbonate $\mathbf{4}$ through cyclization. In this mechanism, the last step is probably very fast as the mixed carbonate intermediate has never been detected under our reaction conditions.

In conclusion, we have developed an efficient catalytic method for the direct formation of vinylene carbonates from aromatic aldehydes. Good yields and selectivities were obtained using an original combination of triazolium salt $\mathbf{L}$ and DMAP, in which DMAP acts both as a base and a nucleophilic catalyst. The reaction scope was investigated with aromatic aldehydes and the corresponding vinylene carbonates were obtained with $32-86 \%$ isolated yields (14 examples). Post-functionalization and derivatization reactions were also reported, showing that vinylene carbonates are attractive platform molecules.

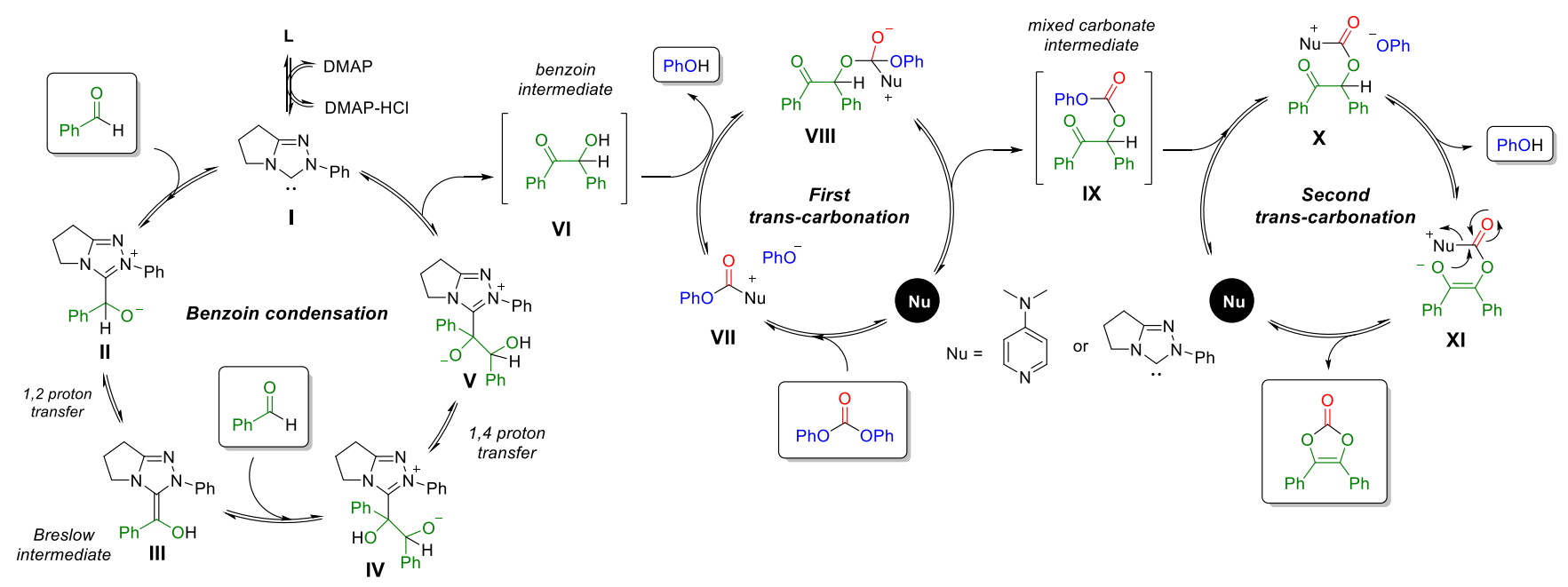




\section{Supporting Information}

Supporting information containing experimental procedures, characterization data and ${ }^{1} \mathrm{H}$ and ${ }^{13} \mathrm{C}$ NMR spectra is given in a separate file.

\section{Corresponding Author}

Dr Nicolas Duguet

+33(0) 472448507

E-mail: nicolas.duguet@univ-lyon1.fr

\section{Acknowledgments}

The authors thank the French National Agency for Research for financial support through a $\mathrm{Ph} . \mathrm{D}$. grant to $\mathrm{K}$. Onida and a master grant to L. Ibrahimli (ANR-19-CE07-0006-ThermoPESO). The authors thank the Auvergne-Rhone-Alpes Region (SCUSI 2017 00936101 ) for partial financial support.

\section{References}

1. Girishkumar, G.; McCloskey, B.; Luntz, A. C.; Swanson, S.; Wilcke, W. Lithium-Air Battery: Promise and Challenges. $J$. Phys. Chem. Lett. 2010, 1, 2193-2203.

2. Schäffner, B.; Schäffner, F.; Verevkin, S. P.; Börner, A. Organic Carbonates as Solvents in Synthesis and Catalysis. Chem. Rev. 2010, 110, 4554-4581.

3. a) Darensbourg, D. J. Making Plastics from Carbon Dioxide: Salen Metal Complexes as Catalysts for the Production of Polycarbonates from Epoxides and $\mathrm{CO}_{2}$. Chem. Rev. 2007, 107, 2388-2410; b) Grignard, B.; Gennen, S.; Jerome, C.; Kleij, A. $\mathrm{W}$.; Detrembleur, C. Advances in the use of $\mathrm{CO}_{2}$ as a renewable feedstock for the synthesis of polymers. Chem. Soc. Rev. 2019, $48,4466-4514$

4. a) Kathalewar, M. S.; Joshi, P. B.; Sabnis, A. S.; Malshe, V. C. Non-isocyanate polyurethanes: from chemistry to applications. $R S C A d v$. 2013, 3, 4110-4129; b) Rokicki, G.; Parzuchowski, P. G.; Mazurek, M. Non-isocyanate polyurethanes: synthesis, properties, and applications. Polym. Adv. Technol. 2015, 26, 707-761; c) Cornille, A.; Auvergne, R.; Figovsky, O.; Boutevin, B.; Caillol, S. A perspective approach to sustainable routes for non-isocyanate polyurethanes. Eur. Polym. J. 2017, 87, 535-552; d) Furtwengler, P.; Averous, L. Renewable polyols for advanced polyurethane foams from diverse biomass resources. Polym. Chem. 2018, 9, 4258-4287; e) Carre, C.; Ecochard, Y.; Caillol, S.; Averous, L. From the Synthesis of Biobased Cyclic Carbonate to Polyhydroxyurethanes: A Promising Route towards Renewable Non-Isocyanate Polyurethanes. ChemSusChem, 2019, 12, 3410-3430.

5. Sakakura, T.; Kohno, K. The synthesis of organic carbonates from carbon dioxide. Chem. Commun. 2009, 1312-1330; b) North, M.; Pasquale, R.; Young, C. Synthesis of cyclic carbonates from epoxides and $\mathrm{CO}_{2}$. Green Chem. 2010, 12, 15141539; c) Comerford, J. W.; Ingram, I. D. V.; North, M.; Wu, X. Sustainable metal-based catalysts for the synthesis of cyclic carbonates containing five-membered rings. Green Chem. 2015, 17, 1966-1987; d) Martín, C.; Fiorani, G.; Kleij, A. W. Recent Advances in the Catalytic Preparation of Cyclic Organic Carbonates. ACS Catal. 2015, 5, 1353-1370; e) Büttner, H.; Longwitz, L.; Steinbauer, J.; Wulf, C.; Werner, T. Recent Developments in the Synthesis of Cyclic Carbonates from Epoxides and $\mathrm{CO}_{2}$. Top. Curr. Chem. 2017, 375, 1-56; f) Shaikh, R. R.; Pornpraprom, S.; D'Elia, V. Catalytic Strategies for the Cycloaddition of Pure, Diluted, and Waste $\mathrm{CO}_{2}$ to Epoxides under Ambient Conditions. ACS Catal. 2018, 8, 419-450; g) Kamphuis, A. J.; Picchioni, F. P.; Pescarmona, P. P. CO $\mathrm{CO}_{2-}$ fixation into cyclic and polymeric carbonates: principles and applications. Green Chem. 2019, 21, 406-448; h) Yadav, N.; Seidi, F.; Crespy, D.; D’Elia, V. Polymers Based on Cyclic Carbonates as Trait d'Union Between Polymer Chemistry and Sustainable $\mathrm{CO}_{2}$ Utilization. ChemSusChem 2019, 12, 724754; i) Aomchad, V.; Cristòfol, À.; Della Monica, F.; Limburg, B.; D’Elia, V.; Kleij, A. W. Recent progress in the catalytic transformation of carbon dioxide into biosourced organic carbonates. Green Chem. 2021, 23, 1077-1113.

6. Aurbach, D.; Gamolsky, K.; Markovsky, B.; Gofer, Y.; Schmidt, M.; Heider, U. On the use of vinylene carbonate (VC) as an additive to electrolyte solutions for Li-ion batteries. Electrochim. Acta 2002, 47, 1423-1439.

7. a) Ding, L.; Li, Y.; Li, Y.; Liang, Y.; Huang, J. Polymerization of vinylene carbonate as well as aminolysis and hydrolysis of poly(vinylene carbonate). Eur. Polym. J. 2001, 37, 2453-2459; b) Kumru, B.; Bicak, N. Synthesis of soluble poly(vinylene carbonate) by redox-initiated RAFT process in microemulsion and its aminolysis yielding snow-white polymethylol. RSC $A d v$. 2015, 5, 30936-30942.

8. a) Stolz, B.; Mönkemeyer, F.; Mader, M.; Schmidt, S.; Volk, L.; Steinberg, T.; Bruchmann, B.; Mülhaupt, R. Polyhydroxymethylenes as Multifunctional High Molecular Weight Sugar Alcohols Tailored for 3D Printing and Medical Applications. Macromol. Chem. Phys. 2020, 221, 2000132; b) Stolz, B.; Mader, M.; Volk, L.; Steinberg, T.; Mülhaupt, R. Cryo-3D Printing of Hierarchically Porous Polyhydroxymethylene Scaffolds for Hard Tissue Regeneration. Macromol. Mater. Eng. 2021, 306, 2000541.

9. a) Jung, M. E.; Blum, R. B.; Gnede, B. J.; Gider, M. R. Preparation and Diels-Alder Cycloadditions of Substituted Vinylene Carbonates (1,3-Dioxol-2-ones) and Related Compounds. Heterocycles 1989, 28, 93-97; b) D'Andrea, S. V.; Freeman, J. P.; Szmuszkovicz, J. Diels-Alder cycloaddition reactions of isobenzofuran and o-quinodimethane with 1,2-diheteroethylenes. J. Org. Chem. 1990, 55, 4356-4358; c) Taffin, C.; Kreutler, G.; Bourgeois, D.; Clot, E.; Périgaud, C. Diels-Alder reaction of vinylene carbonate and 2,5-dimethylfuran: kinetic vs. thermodynamic control. New J. Chem. 2010, 34, 517-525; e) Daub, J.; Trautz, V. Cycloaddition mit vinylencarbonat. Tetrahedron Lett. 1970, 37, 3265-3268; f) Haq, M. Z. Diels-Alder reaction between dimethyl fulvene and vinylene carbonate. Configurational assignments of and magnetic anisotropic studies in adducts and related compounds. J. Org. Chem. 1972, 37, 30153019.

10. Nishii, Y.; Miura, M. Cp*M-Catalyzed Direct Annulation with Terminal Alkynes and Their Surrogates for the Construction of Multi-Ring Systems. ACS Catal. 2020, 10, 9747-9757.

11. a) Ghosh, K.; Nishii, Y.; Miura, M. Rhodium-Catalyzed Annulative Coupling Using Vinylene Carbonate as an Oxidizing Acetylene Surrogate. ACS Catal. 2019, 9, 11455-11460; b) Mihara, G.; Ghosh, K.; Nishii, Y.; Miura, M. Concise Synthesis of Isocoumarins through Rh-Catalyzed Direct Vinylene Annulation: Scope and Mechanistic Insight. Org. Lett. 2020, 22, 5706-5711; c) Ghosh, K.; Nishii, Y.; Miura, M. Oxidative $\mathrm{C}-\mathrm{H} / \mathrm{C}-\mathrm{H}$ Annulation of Imidazopyridines and Indazoles through Rhodium-Catalyzed Vinylene Transfer. Org. Lett. 2020, 22, 3547-3550; d) Li, X.; Huang, T.; Song, Y.; Qi, Y.; Li, L.; Li, Y.; Xiao, Q.; Zhang, Y. Co(III)-Catalyzed Annulative Vinylene Transfer via $\mathrm{C}-\mathrm{H}$ Activation: Three-Step Total Synthesis of 8-Oxopseudopalmatine and Oxopalmatine. Org. 
Lett. 2020, 22, 5925-5930; e) Shen, B.; Liu, S.; Zhu, L.; Zhong, K.; Liu, F.; Chen, H.; Bai, R.; Lan, Y. $\sigma$-Bond Migration Assisted Decarboxylative Activation of Vinylene Carbonate in Rh-Catalyzed $4+2$ Annulation: A Theoretical Study. Organometallics 2020, 39, 2813-2819; f) Wang, L.; Jiang, K.-C.; Zhang, N.; Zhang, Z.-H. Rhodium-Catalyzed Synthesis of Isoquinolino[1,2-b]Quinazolines via C-H Annulation in BiomassDerived $\gamma$-Valerolactone. Asian J. Org. Chem. 2021, 10, 16711674; g) Hu, Y.; Nan, J.; Yin, J.; Huang, G.; Ren, X.; Ma, Y. Rhodium-Catalyzed Dehydrogenative Annulation of N-Arylmethanimines with Vinylene Carbonate for Synthesizing Quinolines. Org. Lett. 2021, 23, 10.1021/acs.orglett.1c03231.

12. Park, M. S.; Moon, K.; Oh, H.; Lee, J. Y.; Ghosh, P.; Kang, J. Y.; Park, J. S.; Mishra, N. K.; Kim, I. S. Synthesis of (2H)-Indazoles and Dihydrocinnolinones through Annulation of Azobenzenes with Vinylene Carbonate under Rh(III) Catalysis. Org. Lett. 2021, 23, 5518-5522.

13. a) Wang, C.; Fan, X.; Chen, F.; Qian, P.-C.; Cheng, J. Ruthenium(II)-Catalyzed $\mathrm{C}-\mathrm{C} / \mathrm{C}-\mathrm{N}$ Coupling of 2-Arylquinazolinones with Vinylene Carbonate: Access to Fused Quinazolinones. Chem. Commun. 2021, 57, 3929-3932; b) Nan, J.; Ma, Q.; Yin, J. Liang, C.; Tian, L.; Ma, Y. RhIII-Catalyzed formal [5 + 1] cyclization of 2-pyrrolyl/indolylanilines using vinylene carbonate as a C1 synthon. Org. Chem. Front. 2021, 8, 1764-1769.

14. a) Hara, H.; Hirano, M.; Tanaka, K. A New Route to Substituted Phenols by Cationic Rhodium(I)/BINAP Complex-Catalyzed Decarboxylative [2+2+2] Cycloaddition. Org. Lett. 2009, 11, 1337-1340; b) Wang, Z.-H.; Wang, H.; Wang, H.; Li, L.; Zhou, M.-D. Ruthenium(II)-Catalyzed $\mathrm{C}-\mathrm{C} / \mathrm{C}-\mathrm{N}$ Coupling of 2-Arylquinazolinones with Vinylene Carbonate: Access to Fused Quinazolinones. Org. Lett. 2021, 23, 995-999.

15. Babu, K. S.; Reddy, M. S.; Tagore, A. R.; Reddy, G. S.; Sebastian, S.; Varma, M. S.; Venkateswarlu, G.; Bhattacharya, A.; Reddy, P. P.; Anand, R. V. J. S. C. Efficient Synthesis of Olmesartan Medoxomil, an Antihypertensive Drug. Synth. Commun. 2008, 39, 291-298.

16. Rádl, S.; Černý, J.; Stach, J.; Gablíková, Z. Improved Process for Azilsartan Medoxomil: A New Angiotensin Receptor Blocker. Org. Process Res. Dev. 2013, 17, 77-86.

17. Park, S.; Jeong, S. Y.; Lee, T. K.; Park, M. W.; Lim, H. Y.; Sung, J.; Cho, J.; Kwak, S. K.; Hong, S. Y.; Choi, N.-S. Replacing conventional battery electrolyte additives with dioxolone derivatives for high-energy-density lithium-ion batteries. Nat. Commun. 2021, 12, 838 .

18. a) Wang, B.; Sun, S.; Cheng, J. The n-dig-Cyclization ( $\mathrm{n}=5$, 6) of Alkynes Involving Fixation of $\mathrm{CO}_{2}$. Synlett 2018, 18141822; b) Sekine, K.; Yamada, T. Silver-catalyzed carboxylation. Chem. Soc. Rev. 2016, 45, 4524-4532; c) Shi, G.; Zhai, R.; Li, H.; Wang, C. Highly efficient synthesis of alkylidene cyclic carbonates from low concentration $\mathrm{CO}_{2}$ using hydroxyl and azolate dual functionalized ionic liquids. Green Chem. 2021, 23, 592-596; d) Cervantes-Reyes, A.; Farshadfar, K.; Rudolph, M.; Rominger, F.; Schaub, T.; Ariafard, A.; Hashmi, A. $\mathrm{S}$. Copper-catalysed synthesis of $\alpha$-alkylidene cyclic carbonates from propargylic alcohols and $\mathrm{CO}_{2}$. Green Chem. 2021, 23, 889-897; e) Cervantes-Reyes, A.; Saxl, T.; Stein, P. M.; Rudolph, M.; Rominger, F.; Asiri, A. M.; Hashmi, A. S. K. Expanded Ring NHC Silver Carboxylate Complexes as Efficient and Reusable Catalysts for the Carboxylative Cyclization of Unsubstituted Propargylic Derivatives. ChemSusChem 2021,
14, 2367-2374; f) Song, Q.-W.; Zhou, Z.-H.; He, L.-N. Efficient, selective and sustainable catalysis of carbon dioxide. Green Chem. 2017, 19, 3707-3728.

19. Ugajin, R.; Kikuchi, S.; Yamada, T. Silver-Catalyzed Efficient Synthesis of Vinylene Carbonate Derivatives from Carbon Dioxide. Synlett 2014, 25, 1178-1180.

20. a) Fischler, H.-M.; Heine, H.-G.; Hartmann, W. Darstellung einiger dialkylsubstituierter vinylencarbonate und ihre photosensibilisierte cycloaddition an äthylen. Tetrahedron Lett. 1972, 17, 1701-1704; b) Torres, M.; Ribo, J.; Clement, A.; Strausz, O. P. The intermediate formation of ketocarbenes and the conformational control in the Wolff rearrangement of $\alpha$-diazoketones. Can. J. Chem. 1983, 61, 996-998.

21. Sahu, D. P. A convenient and safe synthesis of 4,5-disubstituted-2-oxo-1,3-dioxolenes. Indian J. Chem. 2002, 41B, 17221723 .

22. Krayushkin, M. M.; Ivanov, S. N.; Martynkin, A. Yu.; Lichitsky, B. V.; Dudinov, A. A.; Vorontsova, L. G.; Starikova, Z. A.; Uzhinov, B. M. Photochromic dihetarylethenes 17. Synthesis and photochromic properties of dithienylethenes containing new heterocyclic bridging fragments. Russ. Chem. Bull., Int. Ed. 2002, 51, 1731-1736.

23. Onida, K.; Haddleton, A. J.; Norsic, S.; Boisson, C.; D’Agosto, F.; Duguet, N. Organocatalytic Synthesis of Substituted Vinylene Carbonates. Adv. Synth. Catal. 2021, 363, DOI: 10.1002/adsc. 202100870 .

24. a) Hollóczki, O.; Kelemen, Z.; Nyulàszi, L. On the Organocatalytic Activity of N-Heterocyclic Carbenes: Role of Sulfur in Thiamine. J. Org. Chem. 2012, 77, 6014-6022; b) Hollóczki, O. The Mechanism of N-Heterocyclic Carbene Organocatalysis through a Magnifying Glass. Chem. Eur. J. 2020, 26, 48854894.

25. Kaljurand, I.; Kütt, A.; Sooväli, L.; Rodima, T.; Mäemets, V.; Leito, I.; Koppel, I.A. Extension of the Self-Consistent Spectrophotometric Basicity Scale in Acetonitrile to a Full Span of 28 pKa Units: Unification of Different Basicity Scales. J. Org. Chem. 2005, 70, 1019-1028.

26. Massey, R. S.; Collett, C. J.; Lindsay, A. G.; Smith, A. D.; O'Donoghue, A. C. Proton Transfer Reactions of Triazol-3-ylidenes: Kinetic Acidities and Carbon Acid pKa Values for Twenty Triazolium Salts in Aqueous Solution. J. Am. Chem. Soc. 2012, 134, 20421-20432.

27. Gehrke, S.; Hollóczki, O. Are There Carbenes in N-Heterocyclic Carbene Organocatalysis? Angew. Chem. Int. Ed. 2017, 56, 16395-16398.

28. a) Breslow, R. On the Mechanism of Thiamine Action. IV.1 Evidence from Studies on Model Systems. J. Am. Chem. Soc. 1958, 80, 3719-3726; b) Pareek, M.; Reddi, Y.; Sunoj. R. B. Tale of the Breslow intermediate, a central player in N-heterocyclic carbene organocatalysis: then and now. Chem. Sci. 2021, 12, 7973-7992. 